\title{
Sinteza
}

Impact of Internet on Business Activities

in Serbia and Worldwide

Uticaj Interneta na poslovanje u Srbiji i svetu

\section{THE IMPACT OF INFORMATION TECHNOLOGY ON TRAVEL AGENTS IN TIMIŞOARA, ROMANIA}

\section{Cipriana Sava, Adrian Nicolae Mateia}

Faculty of Tourism and Commercial Management Timişoara Christian University

"D.Cantemir"Bucureşti Romania

\begin{abstract}
:
Travel agencies are companies that are positioned between the tourist and tourism providers. Their number increased significantly in Romania after 1990. On the tour operator market in Timisoara tour operators agencies and retailer meet. Towards tourism development act a number of factors, including technological ones. The continuous development of information technology can only bring benefits in the area of tourism.

Part of the current tourism increase is due to the Global Distribution Systems (GDS) and also Alternative Distribution System (ADSS). The advantages of the rapid development of information technologies must be supported by qualified staff who can adapt the trend. This situation forces small operators in finding solutions in order to implement reliable information available globally.
\end{abstract}

\section{Key words:}

travel agencies,

local,

global,

information technology.

\section{INTRODUCTION}

With the development of touristic destinations and general tourism activities, there has been an increase in the number of the tourism agencies - companies that produce and sell various touristic packages.

Travel agencies are considered by Romanian tourism authorities and specialists as "operational units that organize, provide and sell travel services provided by direct providers - hotels, restaurants, transportation, facilities and treatment units etc. They usually sell packages of services grouped in the same tourism program services provided by several providers and handles the publicity and promotion in order to achieve a profit."

The synonym used by the World Tourism Organization (WTO) for a travel agency is tourism agency. Their classification according to the recommendations made by the WTO, which applies in EU countries, divides them into tour operators and retailers.

Agencies tour operators are those who design, prepare and sell tourism products through own retailer points or agents. Thus, we can highlight some differences between the two types of agents.

1 *** Legislație privind turismul, Regia Autonomă, Monitorul Oficial, București,1998, pag.37
Table 1. Differences between types of tourism travel

\begin{tabular}{|c|c|c|c|}
\hline $\begin{array}{l}\text { Nr. } \\
\text { crt. }\end{array}$ & $\begin{array}{c}\text { Criteria of differ- } \\
\text { entiation }\end{array}$ & Tour- operator & Travel agency \\
\hline 1 & $\begin{array}{l}\text { Function per- } \\
\text { formed }\end{array}$ & - producer & - Intermediate agent \\
\hline 2 & Assumed risk & - Commercial high & - Commercial low \\
\hline 3 & Investment effort & - considerable & - reduced \\
\hline 4 & Operating Capital & - very big & - low \\
\hline 5 & $\begin{array}{l}\text { The formation } \\
\text { source of the } \\
\text { income }\end{array}$ & $\begin{array}{l}\text { - trade margin } \\
\text { applied on own } \\
\text { product }\end{array}$ & - commission \\
\hline 6 & Staffing needs & - Quite large & - reduced \\
\hline 7 & $\begin{array}{c}\text { Tourist } \\
\text { relationship }\end{array}$ & - Rare contact & $\begin{array}{l}\text { - Direct and perma- } \\
\text { nent contact }\end{array}$ \\
\hline 8 & $\begin{array}{l}\text { Operating equip- } \\
\text { ment }\end{array}$ & - Outperform & - of strict necessity \\
\hline 9 & $\begin{array}{l}\text { Forming the } \\
\text { request }\end{array}$ & $\begin{array}{l}\text { - Creates the } \\
\text { request }\end{array}$ & $\begin{array}{l}\text { - segmenting and } \\
\text { modeling the } \\
\text { request }\end{array}$ \\
\hline 10 & Area of activity & $\begin{array}{l}\text { - national and } \\
\text { international }\end{array}$ & - local and regional \\
\hline 11 & main Operations & - „outgoing” & $\begin{array}{l}\text { - „incoming” and } \\
\text { „outgoing” }\end{array}$ \\
\hline 12 & $\begin{array}{c}\text { Relations with } \\
\text { tourism authorities }\end{array}$ & - complex & - simple \\
\hline
\end{tabular}

Source: Sava, Cipriana, Gestiunea activității de turism, pag. 11, Ed. Eurostampa, Timişoara, 2010 
The organization, development and maintenance of travel agencies are under the influence of some factors, such as:

- Economic (household income and their changes, tourism offer, prices and tariffs);

- Social (degree of urbanization weekly and yearly paid spare time);

- Technical (performance vehicles, construction technologies, the technical parameters of the facilities and equipment);

- Demographic (population growth, changing life expectancy, population structure by age, sex and socio-professional categories);

- Psychology, education and civilization (education level, desire for knowledge, thirst for culture, temperament, fashion);

- Political and organizational (border formalities, visa arrangements and organized tourism facilities, tourism facilities or priorities organized).

The influence of these factors may be permanent or sporadic. The category of factors which act continuously includes the purchasing power of population, population movement, increased leisure time and political stability. Economic crises, political imbalances, social convulsions, natural disasters and weather conditions are contextual factors.

Cutting-edge technology of computer science has a major contribution in informing potential tourists about the various tourist destinations and assist them in purchasing packages, or components thereof.

Informational technologies

The development and the evolution of the Internet (www) is divided into two periods:

1. Web 1.0: where we find static websites, and there is no user feedback.

2. Web 2.0: in which users can become co-producers, co-designers, co-marketing and co-distributors of touristic services and experiences, as well as co-entrepreneurs of new e-business models. This creates threats, but also enormous opportunities for tourism and hospitality companies. Thus automated management information systems from a web site called Content Management Systems (CMS) have been created. These can dynamically build, on demand, the latest possible version of and only later published on the web is now primarily made directly on the web. Local programs access the web applications more often now because we start from an assumption of permanent connection with the Web. The differences between local and Web applications attenuate. Many programs update themselves by contacting their author's site automatically. The browser role becomes increasingly important because with its help we can implement today's highly complex web applications.

The new web-based applications lead to the effect that users, even when they are not very computer literate, participate directly in spreading information and opinions on the web. From these technologies, the most important are listed below.
Global Distribution Systems („Global Distribution Systems" GDS), derived from computer reservation systems (CRS), were created by airline companies, afterwards travel agencies, tour operators, tourist accommodation structures independent hotel chains, car rental companies, cruise organizers etc connected on them through the internet. These computerized systems allow users to obtain information on availability, rates, reservation and ticket sales. Therefore, we find that, by connecting to the computer network, travel agencies can start to develop tourism products themselves, without having to resort to tour operator companies.

On the international tourist market, global distribution systems are operational and recognized to have an international prestige. The number of users and services provided are constantly evolving. We can mention: Amadeus - Sabre - Galileo and Worldspan 0

From the alternative distribution systems (ADSs) we can mention: Travelocity, Opodo, Travelnow, Expedia, Orbitz. They have the advantage that they can be found in the most travel portals and reach millions of users at a low cost.

Online Distribution Database (ODD), represented by Pegasus, offer a combination of intelligent business and booking and includes services provided by CRS, GDS şi ADSs.

The correct exploitation of the advantages of such a technology can be achieved by developing the infrastructure, the need for education and exposure to best practices worldwide, local and global competition, focusing on innovation and always having a vision for the next stage. A few websites that use the Web 2.0 technology can be found in table 2 .

Table.1. Most visited sites

\begin{tabular}{|c|c|c|}
\hline & Romania & WWW \\
\hline 1 & Amfostacolo.ro & Tripadvisor \\
\hline 2 & Turistinfo.ro & Yahoo!Travel \\
\hline 3 & Infoturism.ro & Booking \\
\hline 4 & Super-cazare.com & Expedia \\
\hline 5 & Paralela45.ro & Priceline \\
\hline
\end{tabular}

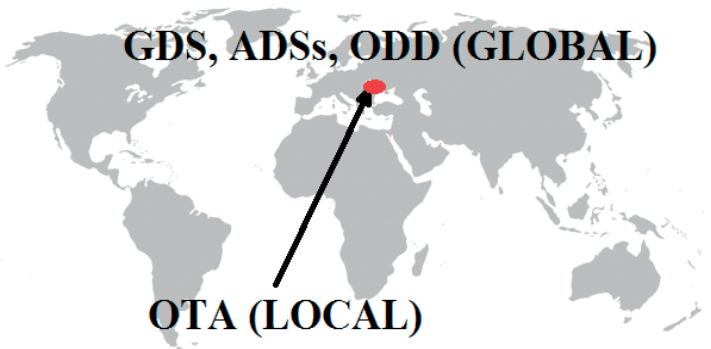

Fig. 1. Reference of OTA to www.

For a local travel agency (OTA), it looks like a tough fight with the big agencies, But Web 2.0 is an environment where, using the right resources and tools available, they have equal opportunities. There are options that can be applied such as TourCMS, Travel Agent CMS, but they are globally designed. The most handy is the proper use 
of SEO and SEM, because Web 2.0 is a based browser and the correct application of keywords lead to the best possible positioning in the lists of search engines. Another useful tool is to use a personal blog, because in the previous table it is seen that in both cases, the first position are site / sites where user opinion count.

To compete effectively with globally integrated enterprises the ability to respond quickly and effectively to changes, opportunities and threats is needed. Thus a superior approach is required and offered by the SOA (Service Oriented Architecture), which is a flexible, standardized architecture that contributes to a better connection between different applications and that facilitates the exchange of information between them. SOA unifies business processes by structuring large applications into a collection of smaller modules called services.

SOA is a software architecture type that involves distributing application functionality into smaller units, distinct - called services - that can be distributed over a network and can be used together to create applications for business. The large capacity in which these services in different applications can be reused is a feature of software architectures based services. These services communicate with each other by sending information from one service to another. SOA is often seen as an evolution of distributed programming and modular programming.

Realized benefits of the SOA implementation include:

Reduced Time to Implement new business processes,

Decreased Development Costs as most of the services were reused;

Enhanced SOA Framework for Further Reuse;

Increased Business Agility and Performance.

\section{TRAVEL AGENCIES IN TIMISOARA, ROMANIA}

Being up to 1990 , a country with a totalitarian regime, Romania has not enabled the existence and functioning of private companies and the same happened in tourism. Travel agencies at that time were the Carpathian National Tourist Office (CNTO) and Youth Travel Bureau (YTB) which had a low tourist offer.

Changes after the events of 1989, both internally and externally have led to numerous travel agents. In 2005, according to data from the National Tourism existing in Romania, the number was 3031, and in 2014 to 3384, increasing by $11.64 \%$ as compared to 2005 is considered, in this case basic.

Timisoara is one of the largest cities in Romania, located in the western part of it, in the Western Plain, with coordinates $45^{\circ} 44^{\prime} 58^{\prime \prime} \mathrm{N}, 21^{\circ} 13^{\prime} 38^{\prime \prime} \mathrm{E}$ and an area of 129.2 $\mathrm{km}^{2}$. Its geographical position, level of development and population is an asset to the establishment and development of travel agencies.

The city's population according to the last census conducted (in 2011) is 319279 people, which makes it the third most populous city in Romania.

From the data obtained from tourism authorities a positive trend can be observed in the number of travel agencies existing in the city.
Table 3 Evolution of the travel agents in Timișoara

\begin{tabular}{|c|c|c|c|}
\hline \multirow{2}{*}{$\begin{array}{c}\text { Year } \\
\text { (1 } \begin{array}{c}\text { st } \\
\text { of Janu- } \\
\text { ary })\end{array}\end{array}$} & $\begin{array}{c}\text { Total } \\
\text { number of } \\
\text { agencies }\end{array}$ & $\begin{array}{c}\text { Tour-oper- } \\
\text { ator }\end{array}$ & Retailer \\
\hline 2005 & 70 & 64 & 6 \\
\hline 2014 & 86 & 73 & 13 \\
\hline
\end{tabular}

Source: National Tourism Authority of Romania in February, 2014

The number of travel agencies in Timisoara on January 1st, 2014 was $22.85 \%$ higher than that recorded on the same date in 2005, mainly as travel agencies tour operator.

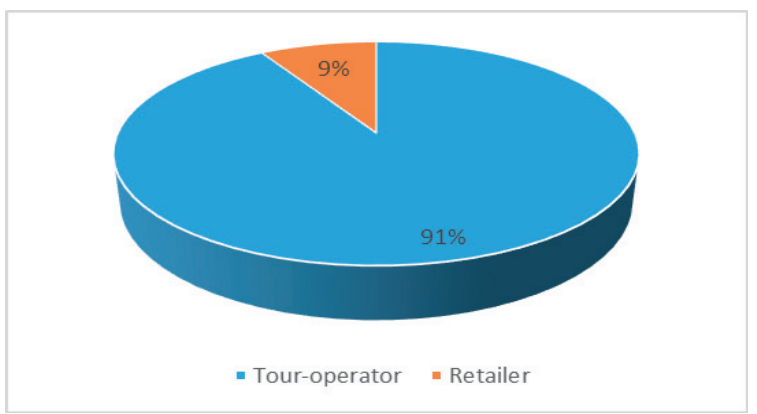

Fig. 2 Travel agencies share by type in 2005

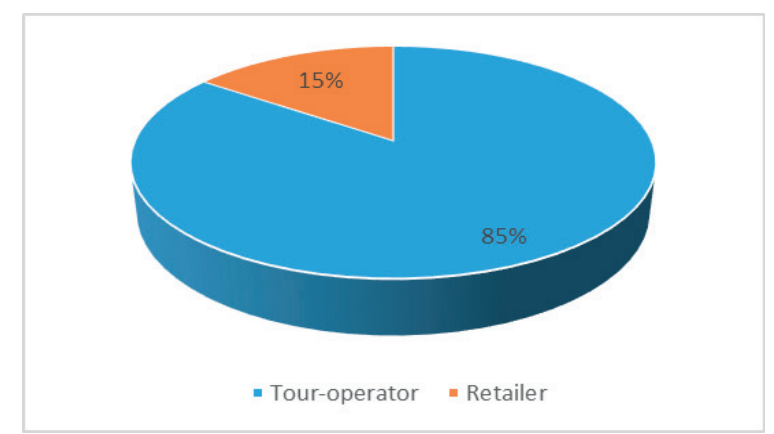

Fig. 3 Travel agencies share by type in 2014

This development has led the travel agencies into a fight for customer loyalty and the attraction of new ones. The agencies which are known in Timisoara due to seriousness, various packages offer and correct prices correlated with quality of service, friendliness, flexibility and availability, but also dynamic websites absorb most of the clients.

For example we chose a travel agency in Timisoara, which has recorded an increase on the number of clients, and inevitable of the income.

Table 3 Evolution of the number of customers in a travel agency from Timisoara

\begin{tabular}{|c|c|c|c|}
\hline \multirow{2}{*}{ Year } & \multirow{2}{*}{$\begin{array}{c}\text { Număr } \\
\text { clienți (per- } \\
\text { soane) }\end{array}$} & $\begin{array}{c}|c| \\
\text { Directly in } \\
\text { the agency } \\
\text { (persons) }\end{array}$ & $\begin{array}{c}\text { Online } \\
\text { reservation } \\
\text { (persons) }\end{array}$ \\
\hline 2005 & 7034 & 6545 & 489 \\
\hline 2013 & 8598 & 6853 & 1745 \\
\hline
\end{tabular}

Source: Travel agency statistics 
As shown, in 2005 only $6.95 \%$ of all clients have resorted to modern technology information, making their reservation online. In 2013 the total number of tourists increased by $22.23 \%$ compared to 2005 , and the number of those who made online bookings was $20.3 \%$ of the agency's clients, meaning that their growth was 1256 people, number of persons near to the number of persons that made the difference as compared to 2005.

We can say that in this case, the modern technology had a positive influence on the travel agency from Timisoara.

From the studies made on travel agencies from Timisoara we noticed an increase in the number of customers per general and the percentage of those who have made online bookings. If in 2005 the share of those who have booked online package holidays was $11.6 \%$ from the total number of customers, in 2013 this share was $24.2 \%$, which show the importance of informational technologies in travel agencies.

\section{CONCLUSIONS}

Travel agencies are important in the trading activity of traveling packages, being intermediaries between future tourists and tourism providers, and we can call them "dream sellers".

The number of companies has increased in recent years in Romania, and also locally, in this case, in Timisoara.

In Timisoara, the online reservations of travel packages presented by the local travel agencies was $24.2 \%$ of the total number of tourist packages sold in 2013, by 12.6 percentage points more than in 2005.
With the appearance of Web 2.0, as we have shown above, users were able to interact with dynamic websites of travel agencies. This was beneficial for smaller agencies enabling them to promote tourism products without having to purchase expensive computer programs for promoting and creating their own websites. Potential customers now have access to the desired information through cheap portals, such as the web browser, and they can choose the best package making an easier and effortlessly comparison between offers in a short time.

Thus, both small travel agencies and customers are favored by the appearance, development and use of informational technologies.

\section{REFERENCES}

[1] Dippelreiter, B.; Grün, C., Pöttler, ., Seidel, I., Berger, H., Dittenbach, M., Pesenhofer, A., - Online Tourism Communities on the Path to Web 2.0 - An Evaluation, Information Technology \& Tourism, Volume 10, Number 4, December 2008 , pp. 329-353(25);

[2] Milano R., Baggio R., Piattelli R., - The effects of online social media on tourism websites 18 th International Conference on Information, Technology and Travel \& Tourism, January 26-28, 2011 - Innsbruck, Austria;

[3] Sava, Cipriana, Gestiunea activității de turism, Ed. Eurostampa, Timișoara, 2010;

[4] http://www-01.ibm.com/software/ro/solutions/soa/;

[5] http://www.tourcms.com/;

[6] ${ }^{* * *}$ National Tourism Authority of Romania in February,2014;

[7] ${ }^{* * *}$ Travel agency statistics 